\title{
Multi-component kinetics for the growth of the cyanobacterium Synechocystis sp. PCC6803
}

\author{
Hyun-Woo Kim ${ }^{1}$, Seongjun Park ${ }^{+}$, Bruce E. Rittmann ${ }^{3}$ \\ ${ }^{1}$ Department of Environmental Engineering, Chonbuk National University, Jeonju 54896, Republic of Korea \\ ${ }^{2}$ Technology Development Team, Construction Technology Division, Samsung C\&T, Seoul 06620, Republic of Korea \\ ${ }^{3}$ Swette Center for Environmental Biotechnology, The Biodesign Institute at Arizona State University, Arizona 85287-5701, USA
}

\begin{abstract}
The growth kinetics of phototrophic microorganisms can be controlled by the light irradiance, the concentration of an inorganic nutrient, or both. A multi-component kinetic model is proposed and tested in novel batch experiments that allow the kinetic parameters for each factor to be estimated independently. For the cyanobacterium Synechocystis sp. PCC6803, the estimated parameters are maximum specific growth rate $\left(\mu_{\max }\right)=2.8 / \mathrm{d}$, half-maximum-rate light irradiance $\left(\mathrm{K}_{\mathrm{L}}\right)=11 \mathrm{~W} / \mathrm{m}^{2}$, half-inhibition-rate light irradiance $\left(\mathrm{K}_{\mathrm{L}, \mathrm{I}}\right)=39 \mathrm{~W} / \mathrm{m}^{2}$, and half-maximum-rate concentration for inorganic carbon $\left(\mathrm{K}_{\mathrm{S}, \mathrm{Gi}}\right)=0.5 \mathrm{mgC} / \mathrm{L}$, half-maximum-rate concentration for inorganic nitrogen $\left(\mathrm{K}_{\mathrm{S}, \mathrm{Ni}}\right)=1.4 \mathrm{mgN} / \mathrm{L}$, and half-maximum-rate concentration for inorganic phosphorus $\left(\mathrm{K}_{\mathrm{S}, \mathrm{Pi}}\right)=0.06 \mathrm{mgP} / \mathrm{L}$. Compared to other phototrophs having $\mu$ max estimates, PCC6803 is a fast-growing $r$-strategist relying on reaction rate. Its half-maximum-rate and half-inhibition rate values identify the ranges of light irradiance and nutrient concentrations that PCC6803 needs to achieve a high specific growth rate to be a sustainable bioenergy source. To gain the advantages of its high maximum specific growth rate, PCC6803 needs to have moderate light illumination $\left(7-62 \mathrm{~W} / \mathrm{m}^{2}\right.$ for $\left.\mu_{\text {syn }} \geq 1 / \mathrm{d}\right)$ and relatively high nutrient concentrations: $\mathrm{N}_{\mathrm{i}} \geq 2.3 \mathrm{mgN} / \mathrm{L}, \mathrm{P}_{\mathrm{i}} \geq 0.1 \mathrm{mgP} / \mathrm{L}$, and $\mathrm{C}_{\mathrm{i}} \geq 1.0 \mathrm{mgC} / \mathrm{L}$.
\end{abstract}

Keywords: Kinetics, Light irradiance, Nutrients, Photoautotrophy, Synechocystis sp. PCC6803

\section{Introduction}

Increasing restrictions on carbon dioxide $\left(\mathrm{CO}_{2}\right)$ discharges and depletion of petroleum reserves warrant attention to utilizing photoautotrophic microorganisms as a means to convert $\mathrm{CO}_{2}$ into biofuels and biomaterials [1-3]. A practical objective is to maximize the biomass-production rate, since the biomass embodies the sunlight energy captured by photosynthesis. Although the photosynthetic pathways in photoautotrophs are complex [4], attempting to embody all of the metabolic details is intractable for practical application to PBR design and operation. Instead, a kinetic representation that captures the core mechanisms of photoautotrophic growth is essential and efficient for design and control of PBRs.

Traditional growth kinetics of photoautotrophs has focused mainly on limitation by light irradiance (L) [5], but such modeling is not accurate when essential nutrients (i.e., inorganic carbon $\left(\mathrm{C}_{\mathrm{i}}\right)$, nitrogen $\left(\mathrm{N}_{\mathrm{i}}\right)$, and phosphorus $\left(\mathrm{P}_{\mathrm{i}}\right)$ ) limit the growth rate. Even though some previous work addressed the effects of $\mathrm{LI}, \mathrm{C}_{\mathrm{i}}$, $\mathrm{N}_{\mathrm{i}}$ and $\mathrm{P}_{\mathrm{i}}$ [6], most previous work has not attempted to identify which component (or components) is (are) rate limiting and then to quantify the kinetic response to all major limiting components. Another unique feature of photoautotrophs is that their overall rate of photosynthesis can be inhibited by excessive LI [7]. This situation is analogous to self-inhibition kinetics for certain organic and inorganic substrates [8]. In contrast, Monod kinetics can be used to represent photosynthetic growth kinetics for individual nutrients [9].

A multiplicative kinetic model appears frequently for dual limitation by the electron donor and electron acceptor for chemotrophic microorganisms [10]. However, this multiplicative model is not directly relevant to photosynthetic microorganisms, which produce energy and reducing power from photophosphorylation and use water as an electron donor; for example, water has a fixed and essentially unlimited concentration. In addition, inorganic nutrients are anabolic building blocks essential for synthesis processes. Even when they need to be reduced (e.g., for $\mathrm{CO}_{2}$ and $\mathrm{NO}_{3}{ }^{-}$), they are reduced for anabolism, not respiration.

To capture these special features of phototrophic microorganisms, we propose a modified hybrid form of a multiplicative kinetic model for the specific growth rate in photosynthesis:
This is an Open Access article distributed under the terms of the Creative Commons Attribution Non-Commercial License (http://creativecommons. org/ licenses/by-nc/3.0/) which permits unrestricted non-commercial use, distribution, and reproduction in any medium, provided the original work is properly cited.
Received April 9, 2015 Accepted September 13, 2015

${ }^{\dagger}$ Corresponding author

Email: sj93.park@samsung.com

Tel: +82-2-2145-6995 Fax: +82-2-2145-6500

Copyright (C) 2015 Korean Society of Environmental Engineers 


$$
\begin{aligned}
\mu_{\text {syn }}= & \mu_{\max } \cdot \frac{L I}{K_{L}+L I+L I^{2} / K_{L I}} \cdot \\
& {\left[\frac{C_{i}}{K_{S, C i}+C_{i}}, \frac{N_{i}}{K_{S, N i}+N_{i}}, \frac{P_{i}}{K_{S, P i}+P_{i}}, \cdots\right]_{\text {min }} }
\end{aligned}
$$

where $\mu_{\text {syn }}$ is the specific growth rate, $\mu_{\max }$ is the maximum specific growth rate, $\mathrm{K}_{S}$ is half-maximum-rate concentration for a given nutrient, $\mathrm{K}_{\mathrm{L}}$ is the half-maximum-rate light irradiance, $\mathrm{K}_{\mathrm{L}, \mathrm{I}}$ is the half-inhibition-rate light irradiance, LI is the light illumination to which the microorganisms are exposed, $\mathrm{K}_{\mathrm{S}, \mathrm{Ci}}$, is the half-maximum-rate concentrations for inorganic carbon, $\mathrm{K}_{\mathrm{S}, \mathrm{Ni}}$ is the half-maximum-rate concentrations for inorganic nitrogen, $\mathrm{K}_{\mathrm{S}, \mathrm{Pi}}$ is the half-maximum-rate concentrations for inorganic phosphorus, $\mathrm{C}_{\mathrm{i}}$ is the total concentration of the carbon, $\mathrm{N}_{\mathrm{i}}$ is the total concentration of the nitrogen, $\mathrm{P}_{\mathrm{i}}$ is the total concentration of the phosphorus, and square bracket with subscript 'min' indicates the minimum value among the individual mathematical expressions separated by commas.

The approach of Eq. (1) expresses that LI drives the oxidation of $\mathrm{H}_{2} \mathrm{O}$ to produce high-energy electrons in the form of nicotinamide adenine dinucleotide phosphate (NADPH) and adenosine- triphosphate (ATP), while synthesis of new biomass is the major sink for the electrons and ATP. The specific growth rate for synthesis is controlled by LI according to self-inhibition kinetics, the first term in Eq. (1). As long as sufficient $\mathrm{NAD}(\mathrm{P}) \mathrm{H}$ and ATP are available from photosynthesis, the synthesis growth rate is controlled solely by the most-limiting inorganic nutrient, the second term in Eq. (1), which follows single-Monod kinetics, consistent with a literature [6]. If LI and a nutrient are concurrently rate limiting, the rate of production of phototrophic-biomass is governed by the multiplicative effect of light intensity (providing the electrons and ATP) and one most-limiting nutrient (controlling synthesis, the sink for the electrons and ATP), as shown by all of Eq. (1).

In determining the specific growth rate using Eq. (1), the locally available LI inside the PBR becomes essential, since LI varies with the length of the light path and biomass concentration according to the Beer-Lambert law [11]. It is convenient to compute an average LI integrated over the entire volume of the PBR [12], as this provides a single value for $\mathrm{LI}$, which we call $\mathrm{LI}_{\mathrm{SA}}$, as it is the spatially averaged value. The contents of PBRs normally are well mixed so that the photosynthetic microorganisms are exposed to $\mathrm{LI}_{\mathrm{SA}}$ on average. Thus, the multiplicative form captures that LI is readily attenuated in most experimental conditions by either the system's boundary or the biomass itself.

The primary objectives of this study are to evaluate the hybrid multiplicative model (Eq. (1) using $\mathrm{LI}_{\mathrm{SA}}$ ) for photoautotroph synthesis and to estimate the kinetic parameters for each of $\mathrm{LI}_{\mathrm{SA}}$, $\mathrm{C}_{\mathrm{i}}, \mathrm{N}_{\mathrm{i}}$, and $\mathrm{P}_{\mathrm{i}}$. We do so by using the cyanobacterium Synechocystis sp. PCC6803 and a specially designed series of batch experiments.

Synechocystis sp. PCC6803 is a good model photoautotroph, since it can achieve high biomass yield and is robust for wide ranges of temperature, salinity, and $\mathrm{pH}$ [13]. Moreover, the simple genetic structure of PCC6803 provides an opportunity to improve physiological characteristics through genetic manipulations [14]. Whether PCC6803 is wild type or genetically modified, enhancing its productivity will depend on identifying and quantifying the factors that limit its growth-rate in a photobioreactor (PBR) since ultimate goal is characterizing how to synthesize more biomass within shorter period of time.

We designed special batch experiments to allow the kinetic parameters for each factor to be estimated independently. We considered light attenuation to compute $\mathrm{LI}_{\mathrm{SA}}$ inside the bioreactor and used $\mathrm{LI}_{\mathrm{SA}}$ whenever LI was limiting. We evaluated the multiplicative connection between LI and the limiting nutrient, as well as self-inhibition by $\mathrm{LI}_{\mathrm{SA}}$. With estimates for all the kinetic parameters, we are able to assess the conditions that lead to a significantly high specific growth rate of PCC6803, $\geq 1 / \mathrm{d}$.

\section{Materials and Methods}

\subsection{Batch-Experiment Set Up}

All batch experiments were conducted in 125-mL serum bottles (Wheaton Science Products, USA) made of clear borosilicate glass and with a liquid volume of $100 \mathrm{~mL}$. The experimental set up is shown schematically in Fig. S1 of Supporting Information. The mouth was sealed with a snap-on rubber stopper and an aluminum cap after filling the bottle with medium. Gas-flow controllers, connected to an air pump (KNF Neuberger, USA) with an air-filter (0.2 mm PTFE; Whatmann, USA) inlet, regulated the supply rate of $\mathrm{CO}_{2}$ by maintaining an aeration rate of $5 \mathrm{~L} \mathrm{~L}_{\text {air }} / \mathrm{L}_{\text {reactor }} / \mathrm{min}$ through a tube inserted into the bottle through the rubber cap. The rapid gas bubbling make the liquid contents completely mixed, and off gas was vented out through a syringe needle while preventing mass transfer limitation of $\mathrm{C}_{\mathrm{i}}$.

The batch experiments were performed in a photo-incubation chamber (TC30; Conviron Inc., USA) maintained at $30^{\circ} \mathrm{C}$. Light panels inside the chamber were equipped with white-fluorescent lamps and supplied photosynthetically active radiation (PAR)[15] with a controllable LI in the range of $3-20 \mathrm{~W} / \mathrm{m}^{2}(14-92 \mathrm{mmol}$ photons $/ \mathrm{s} / \mathrm{m}^{2}$ ) at the outside of the bottle. For attaining LI levels up to $48 \mathrm{~W} / \mathrm{m}^{2}$ (221 mmol photons $/ \mathrm{s} / \mathrm{m}^{2}$ ), additional lamps were 92 installed. The PAR LI was measured with a PAR sensor (LI-190 Quantum sensor; LI-COR Biosciences, USA) connected to a digital multi-meter; thus, all the LI values reported in this study are on a PAR basis. The photon flux was converted to energy flux using $4.6 \mathrm{mmol}$ photons $/ \mathrm{s} / \mathrm{m}^{2}$ per $\mathrm{W} / \mathrm{m}^{2}$ [15].

\subsection{Inoculum and Culture Media}

PCC6803 was cultivated in a 5-L mother culture grown in a transparent 10-L reservoir bottle (KIMAX, Germany) to which we sparged filtered air $\left(2 \mathrm{~L} \mathrm{~L}_{\text {air }} / \mathrm{L}_{\text {liquid }} / \mathrm{min}\right)$. The bottle was continuously illuminated using fluorescent lamps $\left(20 \mathrm{~W} / \mathrm{m}^{2}\right.$ on the exterior) in the same photo-incubator chamber. Non-limiting $\mathrm{N}_{\mathrm{i}}, \mathrm{P}_{\mathrm{i}}$, and other nutrients were supplied using standard BG-11 medium to which we added supplemental $\mathrm{P}_{\mathrm{i}}$ using a semi-batch mode of operation (hydraulic retention time $\cong 10 \mathrm{~d}$ ) [16]. Thus, inocula taken from the mother culture had been experiencing feast-and-famine nutrient conditions. Inoculum cultures were kept at a $730-\mathrm{nm}$ optical density $\left(\mathrm{OD}_{730}\right)$ of 2.3 , which is defined as $-\log _{10}\left(\mathrm{I} / \mathrm{I}_{0}\right)$, where $\mathrm{I}$ is the intensity of light at a 730-nm wavelength that has passed through a sample and $I_{0}$ is the intensity of the light before it enters the sample. 
For the batch experiments, the standard BG-11 growth medium [17] was modified to achieve limitation independently by each nutrient. For all experiments, we removed the usual amount of $\mathrm{Na}_{2} \mathrm{CO}_{3}$ from standard BG-11 solutions in order to have independent control of $\mathrm{C}_{\mathrm{i}}$; we call this BG-11C, which contained $1.5 \mathrm{~g} \mathrm{NaNO}_{3}$, $40 \mathrm{mg} \mathrm{K} \mathrm{HPO}_{4} \cdot 3 \mathrm{H}_{2} \mathrm{O}, 75 \mathrm{mg} \mathrm{MgSO}_{4} \cdot 7 \mathrm{H}_{2} \mathrm{O}, 36 \mathrm{mg} \mathrm{CaCl} 2 \cdot 2 \mathrm{H}_{2} \mathrm{O}$, $6 \mathrm{mg}$ citric acid, $6 \mathrm{mg}$ ferric ammonium citrate, $1 \mathrm{mg}$ EDTA disodium salt, and $1 \mathrm{ml}$ mixed trace metal solution. Each liter of trace metal solution contained $2.9 \mathrm{~g} \mathrm{H}_{3} \mathrm{BO}_{3}$, $1.8 \mathrm{~g} \mathrm{MnCl}_{2} \cdot 4 \mathrm{H}_{2} \mathrm{O}, 0.22 \mathrm{~g}$ $\mathrm{ZnSO}_{4} \cdot 7 \mathrm{H}_{2} \mathrm{O}, 0.39 \mathrm{~g} \mathrm{NaMoO}_{4} \cdot 2 \mathrm{H}_{2} \mathrm{O}, 79 \mathrm{mg} \mathrm{CuSO} \cdot 5 \mathrm{H}_{2} \mathrm{O}$, and $49 \mathrm{mg}$ $\mathrm{Co}\left(\mathrm{NO}_{3}\right)_{2} \cdot 6 \mathrm{H}_{2} \mathrm{O}$ in deionized water (conductivity $=18.2 \mathrm{M} \Omega \cdot \mathrm{cm}$ ) produced by Purelab Ultra (ELGA lab water, USA). Further modifications were made to BG-11C for each batch experiments, as described below, and all media were autoclaved before use.

\subsection{Batch-experiment Procedures}

Table 1 summarizes the four sets of batch experiments to estimate each kinetic parameter. We first used batch experiment 1 to obtain the parameters for LI-controlled kinetics first. It had ample $\mathrm{N}_{\mathrm{i}}$, $\mathrm{P}_{\mathrm{i}}$, and $\mathrm{C}_{\mathrm{i}}$ at all times so that only $\mathrm{LI}$ was limiting. Using optimal-LI conditions revealed in experiment 1 , we then conducted batch experiments 2, 3, and 4 to determine parameters $\mathrm{K}_{\mathrm{S}, \mathrm{Ni}}, \mathrm{K}_{\mathrm{S}, \mathrm{Pi}}$, and $\mathrm{K}_{\mathrm{S}, \mathrm{Ci}}$, respectively. The rightmost column in Table 1 indicates the range we tested for each independent variable. In all cases, the stoichiometric consumption of the limiting nutrient was small compared to its starting concentration.

Each series of batch experiment was begun by filling all the test bottles with $97 \mathrm{~mL}$ of modified medium according to Table 1 and adjusting the $\mathrm{pH}$ to $8 \pm 0.2$ using a phosphate buffer $\left(\mathrm{H}_{2} \mathrm{PO}_{4}{ }^{-}\right.$ and $\mathrm{HPO}_{4}^{2-}$ at a 7:43 mole ratio) and $0.2 \mathrm{M}$ hydrochloric acid or $0.2 \mathrm{M}$ sodium hydroxide. The $\mathrm{pH}$ was monitored using a $\mathrm{pH}$ meter (Accumet AB15; Fisher scientific, USA) with a glass $\mathrm{pH}$ electrode. We put the reactors inside the incubator overnight to establish the same temperature. The next day, we began aeration for the reactors of experiments 1 to 3 using gas-flow-rate controllers (5 $\mathrm{L}_{\text {air }} / \mathrm{L}_{\text {liquid }} / \mathrm{min}$ ) and inoculated $3 \mathrm{~mL}$ of mother culture with dis-

Table 1. Experimental Design for the Estimation of Kinetic Constants (The experimental set up for these experiments is shown schematically in Fig. S1 in Supporting Information.)

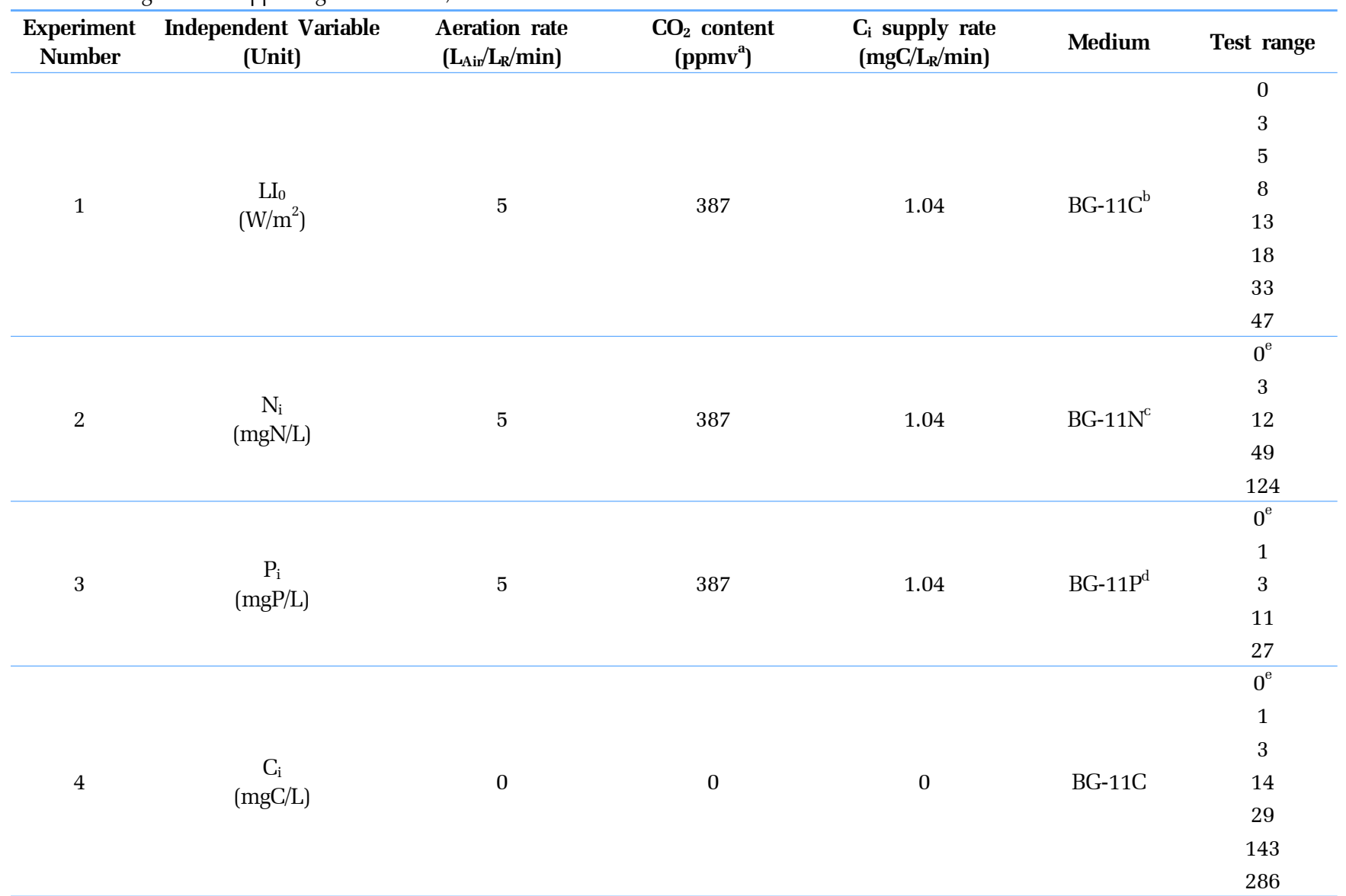

\footnotetext{
${ }^{a}$ Part per million by volume from NOAA/ESRL (http://www.esrl.noaa.gov/gmd/ccgg/trends/).

${ }^{\mathrm{b}}$ Modified BG-11 without $\mathrm{Na}_{2} \mathrm{CO}_{3}$.

${ }^{c}$ Modified BG-11C without $\mathrm{NaNO}_{3}$. We independently added $\mathrm{NaNO}_{3}$ to meet the target concentration.

${ }^{d}$ Modified BG-11C without $\mathrm{K}_{2} \mathrm{HPO}_{4} \cdot 3 \mathrm{H}_{2} \mathrm{O}$. We independently added $\mathrm{K}_{2} \mathrm{HPO}_{4} \cdot 3 \mathrm{H}_{2} \mathrm{O}$ to meet the target concentration.

e Control experiment testing zero concentration.
} 
posable syringes and needles. The $\mathrm{C}_{\mathrm{i}}$-supply rate (mg $\left.\mathrm{C} / \mathrm{L}_{\text {reactor }} / \mathrm{min}\right)$ was based on the $\mathrm{CO}_{2}$-aeration rate $\left(\mathrm{L}_{\mathrm{air}} / \mathrm{L}_{\mathrm{R}} / \mathrm{min}\right)$, the $\mathrm{CO}_{2}$ content in the air $(\sim 380 \mathrm{ppm}, \mathrm{v} / \mathrm{v})$, the ideal-gas assumption $(1 \mathrm{~mol}=22.4$ L) under standard temperature and pressure, and the molar mass of $C(12 \mathrm{~g} / \mathrm{mol})$. For estimating $C_{i}$ kinetics in experiment 4 , we added different amounts of $\mathrm{NaHCO}_{3}$ to meet the $\mathrm{C}_{\mathrm{i}}$ goal of each test, instead of supplying $\mathrm{C}_{\mathrm{i}}$ by aeration; this approach allowed us to maintain a constant total- $\mathrm{C}$ content ( $=$ residual $\mathrm{C}_{\mathrm{i}}+\mathrm{C}$ in biomass) in each bottle. Although experiment 4 was not aerated, we inoculated it in the usual way and shook the bottles by hand to mix their contents at the start of the experiment and before each sampling. In addition, any produced gas was vented using a disposable syringe needle to relieve pressure build up. Since PCC6803 remained in a stable suspension for up to two days, the liquid contents for experiment 4 experienced no loss of biomass concentration due to sedimentation between samplings. The $\mathrm{pH}$ of $\mathrm{BG}-11 \mathrm{C}$ was $8 \pm 0.2$, which indicates that dominant $\mathrm{C}_{\mathrm{i}}$ species was $\mathrm{HCO}_{3}^{-}[18]$.

The initial $\mathrm{OD}_{730}$ ranged from $0.08-0.10$, which corresponded to $21-27 \mathrm{mg} / \mathrm{L}$ as dry weight (DW). This low initial biomass concentration and excess concentrations of nutrients guaranteed minimal LI attenuation at the start of the experiment 1. Furthermore, we took samples during the initial 4 hours, when $\mathrm{OD}_{730}$ remained less than 0.3 (Fig. S2 in supporting information). Based on our previous research [16], the specific growth rate adjusts to the new experimental conditions for $\mathrm{LI}, \mathrm{C}_{\mathrm{i}}, \mathrm{N}_{\mathrm{i}}$, and $\mathrm{P}_{\mathrm{i}}$ within an hour; thus, the $\mathrm{OD}_{730}$ was utilized results from 1 to 4 hours.

We performed quadruplicate experiments in four reactors for each experimental condition. Thus, we present the average specific growth rate with a standard deviation from the 4 reactors. Variability was small among the tests and may have originated from small differences in acclimation to the new conditions, inoculum size, carryover of nutrients with the inoculums, and sampling timing.

\subsection{Control Experiments}

We also carried out an upper control experiment with all nutrients present and a series of lower control experiments with one nutrient totally absent (Fig. S2 of the Supporting Information). The upper control results indicate that the maximum $\mu$ was $>1.6 / \mathrm{d}$. For the lower controls, the inocula were washed three times in $0.9 \% \mathrm{NaCl}$ solution to remove residual nutrient from the inoculum's growth medium before conducting each experiment. The lower control results document that eliminating any one nutrient suppressed biomass growth so that the biomass increase over $4 \mathrm{~h}$ was a maximum of $8.0 \mathrm{mg} / \mathrm{L}$ or $0.03 \mathrm{OD}_{730}$. Because the change in biomass was so small in the lower controls, we were able to use directly the biomass concentrations in non-control experiments (Table 1).

\subsection{Sampling and Analytical Methods}

The growth kinetics of PCC6803 were monitored by analyzing 2-mL liquid samples taken at 0,1 , and 4 hours with a disposable syringe using a needle inserted through the rubber cap. $\mathrm{OD}_{730}$ was directly measured with a UV-visible spectrophotometer (Cary 50 Bio; Varian Inc., USA) at a wavelength of $730 \mathrm{~nm}$ and was converted to DW using calibration curve that we determined for PCC6803, shown in Fig. S3 of Supporting Information. For the calibration, DW was determined using total suspended solids
(Method 2540D in Standard Methods) [19].

The specific growth rate was computed for synthesis based on biomass concentrations in samples taken at the beginning and end of a time interval:

$$
\mu=\mu_{\text {syn }}-b=\frac{\ln X_{4}-\ln X_{1}}{t_{r}-t_{1}}
$$

where $\mu$ is the observed net specific growth rate $(/ d), \mu_{\text {syn }}$ is the synthesis specific growth rate $(/ \mathrm{d}), \mathrm{b}$ is the endogenous decay rate $(/ \mathrm{d})$, and $\mathrm{X}_{1}$ and $\mathrm{X}_{4}$ are the biomass concentrations (expressed by mg DW/L) at time 1 and 4 hours (t1 and t4), respectively. Independently, b was estimated by the decrease of biomass concentration under complete darkness for one day; the value was $0.056 / \mathrm{d}$, as presented in Table S1 of Supporting Information.

To obtain the best estimates of the kinetic parameters for LI, $\mathrm{N}_{\mathrm{i}}, \mathrm{P}_{\mathrm{i}}$ and $\mathrm{C}_{\mathrm{i}}$ from each set of experiments, we conducted non-linear regression using computer software (Sigmaplot10; Systat Software Inc., USA) that related the observed $\mu_{\text {syn }}=\mathrm{m}+\mathrm{b}$ to the spatially averaged light intensity ( $\left.\mathrm{LI}_{\mathrm{SA}}\right)$ and the concentration of the limiting nutrient at a fixed $\mathrm{LI}_{\mathrm{SA}}$. For estimating parameters associated with $\mathrm{N}_{\mathrm{i}}, \mathrm{P}_{\mathrm{i}}$, and $\mathrm{C}_{\mathrm{i}}$ kinetics in experiments 2 - 4, we employed the best-fit constants for LI revealed previously in experiment 1 . This strategy made it possible for us to use the experimental data for each nutrient to estimate only one corresponding parameter $\left(\mathrm{K}_{\mathrm{S}}\right)$.

\subsection{Light Attenuation}

Average LI integrated over the entire PBR volume representing spatially averaged value, $\mathrm{LI}_{\mathrm{SA}}$, was computed in $\mathrm{W} / \mathrm{m}^{2}$ as PAR based on these assumptions: a transparent cylindrical shape, uniform illumination from all sides, no light absorption by the biomass-free medium, no top and bottom effects, and light attenuation according to the Beer-Lambert law [12]. Supporting Information (Fig. S4) provides details of the geometry involved in the calculation. The equation for $\mathrm{LI}_{\mathrm{SA}}$ is:

$$
\begin{aligned}
L I_{S A} & =\frac{L I_{o}}{A_{n}} \int_{0}^{2 \pi} \int_{0}^{R} I_{n}(X, r, \theta) \cdot r d r d \theta \\
& =\frac{L I_{o}}{\pi R^{2}} \int_{0}^{2 \pi} \int_{0}^{R} e^{-\epsilon X\left[r \cdot \cos \theta+\sqrt{R^{2}-r^{2} \cdot \sin ^{2} \theta}\right] r d r d \theta}
\end{aligned}
$$

where $\mathrm{L}_{0}=\mathrm{LI}$ at the light-entry surface $\left(\mathrm{W} / \mathrm{m}^{2}\right), \varepsilon=$ the Beer-Lambert constant $\left(\mathrm{m}^{3} / \mathrm{g} / \mathrm{m}\right), X=$ biomass concentration $\left(\mathrm{g} / \mathrm{m}^{3}\right)$, and $\mathrm{d}=$ depth of light path from the light-entry surface (m). Suh and Lee[11] verified that e for Synechococcus sp. PCC6301 is $0.255 \mathrm{~m}^{3} / \mathrm{g} / \mathrm{m}$. Our preliminary study with PCC6803 found a similar value from light-attenuation experiments conducted within our ranges of biomass concentration using PCC6803. Therefore, we utilized $\varepsilon=0.255$ $\mathrm{m}^{3} / \mathrm{g} / \mathrm{m}$ to calculate $\mathrm{LI}_{\mathrm{SA}}$, and the $\mathrm{LI}_{\mathrm{SA}}$ was used in Eq. (1).

\section{Results and Discussion}

\subsection{Substrate-Inhibition Kinetics for $\mathrm{LI}_{\mathrm{SA}}$}

Table S2 shows the calculated $\mathrm{LI}_{\mathrm{SA}}$ values using the measured biomass concentrations and $\mathrm{LI}_{0}$ at the start of each batch 
experiment. With $\mathrm{LI}_{0}$ outside the batch reactor varying from 2.6 to $48 \mathrm{~W} / \mathrm{m}^{2}, \mathrm{LI}_{\mathrm{SA}}$ ranged from 2.3 to $43 \mathrm{~W} / \mathrm{m}^{2}$. The attenuation was $\sim 13 \%$ of $\mathrm{LI}_{0}$ with the biomass concentrations of $\sim 27 \mathrm{mg}$ DW/L.

Fig. 1 shows the observed $\mu_{\text {syn }}$ values based on biomass measurements taken at 1 and 4 hours for each $\mathrm{L}_{\mathrm{SA}}$. These results demonstrate the expected trends for LI self-inhibition kinetics: increasing $\mu_{\text {syn }}$ for $\mathrm{LI}_{\mathrm{SA}}$ up to about $8 \mathrm{~W} / \mathrm{m}^{2}$, relatively steady $\mu_{\text {syn }}$ from about 10 to $25 \mathrm{~W} / \mathrm{m}^{2}$, and decreasing $\mu_{\mathrm{syn}}$ for $\mathrm{LI}_{\mathrm{SA}}$ greater than $\sim 30 \mathrm{~W} / \mathrm{m}^{2}$. The highest observed $\mu_{\text {syn }}$ was approximately $1.5 / d$ for LISA of $\sim 30 \mathrm{~W} / \mathrm{m}^{2}$.

Non-linear regression yielded $\mu_{\max }$ of $2.8 / \mathrm{d}, \mathrm{K}_{\mathrm{L}}=11 \mathrm{~W} / \mathrm{m}^{2}$, and $\mathrm{K}_{\mathrm{L}, \mathrm{I}}=39 \mathrm{~W} / \mathrm{m}^{2}$. The value of $\mu_{\max }$ was significantly larger than 1.5/d because of $\mathrm{LI}$ inhibition, which is quantified by the relatively low value of $\mathrm{K}_{\mathrm{L}, \mathrm{I}}$. Based on the LI kinetic model, PCC6803 achieve a benchmark $\mu_{\text {syn }} \geq 1 / d$ when $L_{S A}$ is in the range of 7 to $62 \mathrm{~W} / \mathrm{m}^{2}$.

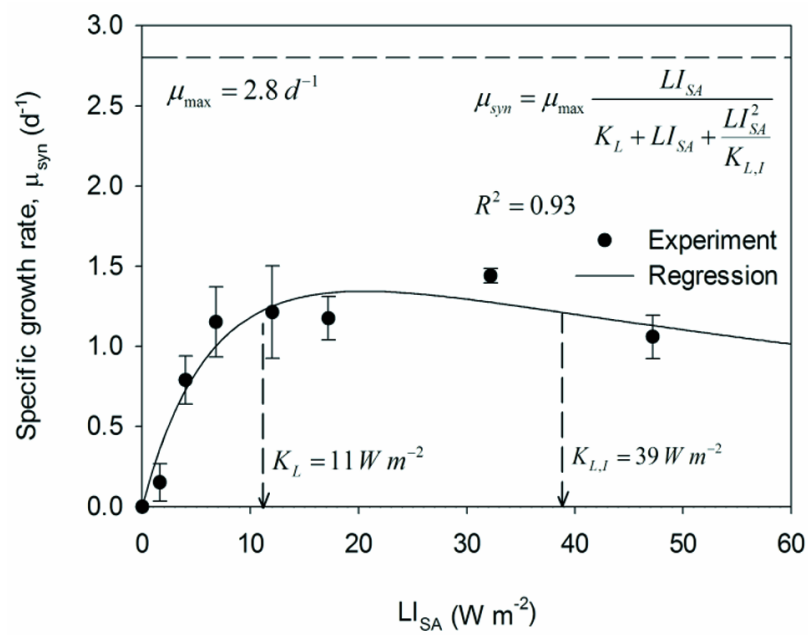

Fig 1. Specific growth rates $\left(\mu_{s, n}\right)$ for the range of $L_{S A}$ values for experiment 1 and the corresponding regression results using the self-inhibition kinetic model (inset).

\subsection{Monod Kinetics for $N_{i}, P_{i}$, and $C_{i}$}

Using the results for LI kinetics (experiment 1, which had sufficient $\mathrm{N}_{\mathrm{i}}, \mathrm{P}_{\mathrm{i}}$, and $\mathrm{C}_{\mathrm{i}}$ ), we could obtain parameter estimates for the growth kinetics of PCC6803 for each nutrient limitation (experiments $2-4$ ). We chose $\mathrm{LI}_{0}=18 \mathrm{~W} / \mathrm{m}^{2}$ to keep the initial $\mathrm{LI}_{\mathrm{SA}}$ at around 16 $\mathrm{W} / \mathrm{m}^{2}$, which is in the range where $\mathrm{LI}_{\mathrm{SA}}$ does not have a sensitive effect on $\mu_{\text {syn }}$ (Fig. 1). In each experimental series, we computed the LI-adjusted $\mu_{\max }$ value from Eq. (1) and the actual $\mathrm{LI}_{\mathrm{SA}}$ value; we call this value $\mu_{\text {syn }}$, LI.

Experiment 2 evaluated the kinetics for $\mathrm{N}_{\mathrm{i}}$ limitation, and Fig. 2 shows $\mu_{\text {syn }}$ for $\mathrm{N}_{\mathrm{i}}$ varying from 0 to $124 \mathrm{mgN} / \mathrm{L}$. The results clearly exhibit a Monod-type saturation pattern with $\mu_{\text {syn }}$ saturating at $\mu_{\text {syn,LI }}=1.6 / \mathrm{d}$ (based on LI limitation from experiment 1). Non-linear regression $\left(\mathrm{R}^{2}=0.97\right)$ yields $\mathrm{K}_{\mathrm{S}, \mathrm{Ni}}=1.4 \mathrm{mgN} / \mathrm{L}$. This value means that the $\mathrm{NO}_{3}{ }^{-}$concentration in a PBR should be greater than $13 \mathrm{mgN} / \mathrm{L}$ to maintain $90 \%$ of the maximum specific growth rate, but the rate is slowed to $10 \%$ of the maximum value when the $\mathrm{NO}_{3}^{-}$concentration falls below $0.16 \mathrm{mgN} / \mathrm{L}$. Serious $\mathrm{N}_{\mathrm{i}}$-limitation of cyanobacteria is highly undesirable, because it can cause visible chlorosis, or yellowish coloring of the cells due to the degradation of thylakoid membranes [20] or a decrease in their chlorophyll content [21]. Keeping $\mathrm{N}_{\mathrm{i}}$ over $2.3 \mathrm{mgN} / \mathrm{L}$ in a PBR is necessary for growing PCC6803 at a benchmark $\mu_{\text {syn }}$ of at least $1 / d$ (with $\mathrm{LI}_{\mathrm{SA}} \sim 16 \mathrm{~W} / \mathrm{m}^{2}$ ).

Fig. 3 shows the photosynthetic specific growth rate as a function of the total- $\mathrm{P}_{\mathrm{i}}$ concentration in experiment 3. With the $\mathrm{pH}$ held constant at $8 \pm 0.2$, the dominant $\mathrm{P}_{\mathrm{i}}$ species were $\mathrm{H}_{2} \mathrm{PO}_{4}{ }^{-}$and $\mathrm{HPO}_{4}{ }^{2-}$, present at a molar ratio of 7:43. Thus, the corresponding ranges for $\mathrm{H}_{2} \mathrm{PO}_{4}{ }^{-}$and $\mathrm{HPO}_{4}{ }^{2-}$ concentrations were $0.14-3.8 \mathrm{mgP} / \mathrm{L}$ and 0.86-23 mgP/L, respectively. The experiments showed an almost constant $\mu_{\text {syn }}$ value (1.6/d) for total- $P_{i}$ concentrations of $3 \mathrm{mgP} / \mathrm{L}$ and higher. Only when the total- $P_{i}$ concentration was less than $1 \mathrm{mgP} / \mathrm{L}$, the lowest concentration tested except the control, did $\mu_{\text {syn }}$ show a slightly lower value, $1.4 /$ d.

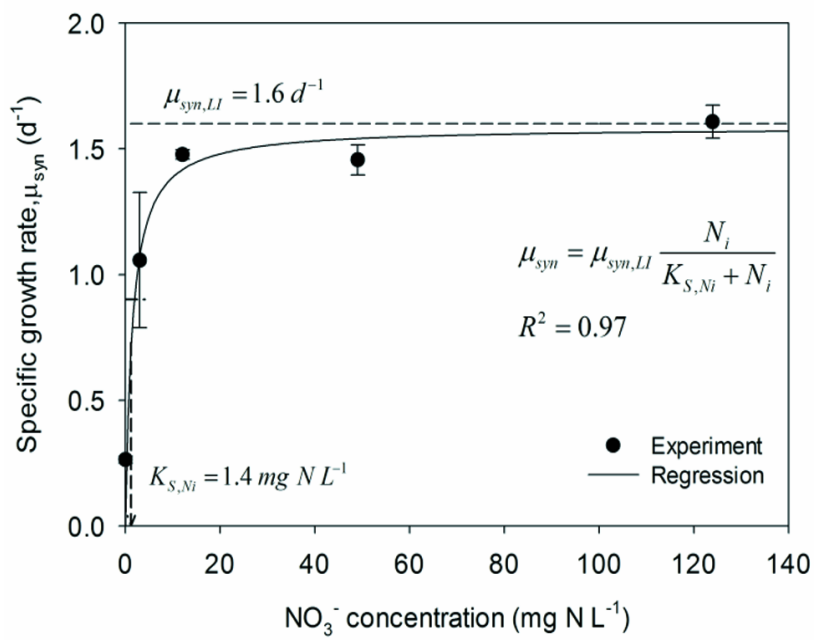

Fig. 2. Specific growth rates $\left(\mu_{\mathrm{syn}}\right)$ for the range of $\mathrm{N}_{\mathrm{i}}$ concentrations for experiment 2 and the corresponding regression results using the Monod model (inset).

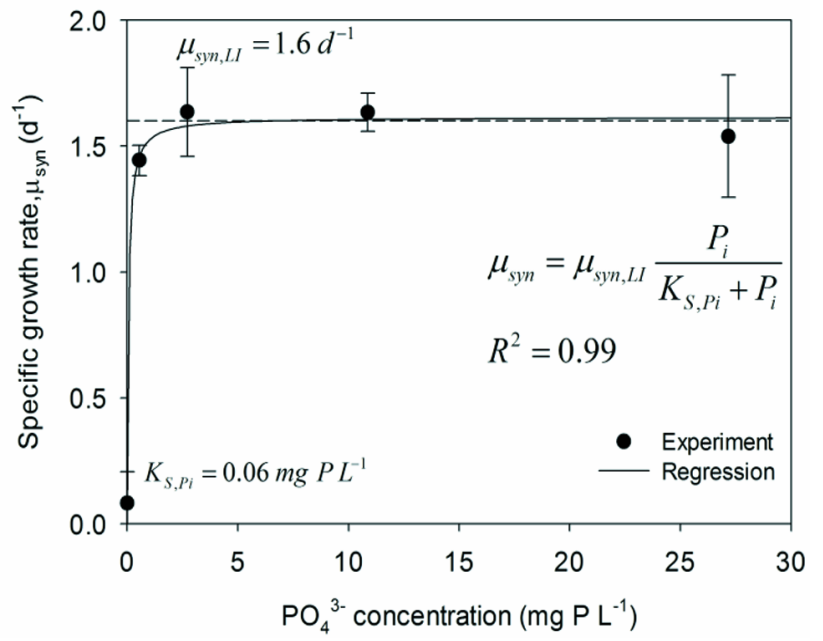

Fig. 3. Specific growth rates $\left(\mu_{\text {syn }}\right)$ for the range of $P_{i}$ concentrations for experiment 3 and the corresponding regression results using a Monod model (inset). At $\mathrm{pH} 8$, the molar ratio of $\mathrm{H}_{2} \mathrm{PO}_{4}{ }^{-}: \mathrm{HPO}_{4}{ }^{2-}=7: 43$, while $\mathrm{H}_{3} \mathrm{PO}_{4}$ and $\mathrm{PO}_{4}{ }^{3-}$ are negligible. 
Applying $\mu_{\text {syn,LI }}$ (1.6/d) gave a good match of the Monod function to the experimental results and led to an estimated $\mathrm{K}_{\mathrm{S}, \mathrm{Pi}}$ of 0.06 $\mathrm{mgP} / \mathrm{L}$ for total $\mathrm{P}_{\mathrm{i}}\left(\mathrm{R}^{2}=0.99\right)$. This low $\mathrm{K}_{\mathrm{S}, \mathrm{Pi}}$ value indicates very high affinity for $\mathrm{P}_{\mathrm{i}}$ and that it is not necessary to maintain a high concentration of $\mathrm{P}_{\mathrm{i}}$ in the PBR, compared to what is required for $N_{i}$. For example, maintaining $\mu_{\text {syn }} \geq 1 / d$ demands that the total- $P_{i}$ concentration be at least $0.1 \mathrm{mgP} / \mathrm{L}$.

Although a high specific growth rate does not require a high $\mathrm{P}_{\mathrm{i}}$ concentration, it is very important to monitor the $\mathrm{P}_{\mathrm{i}}$ concentration and ensure that it does not become seriously limiting. Previous studies reported that a deficiency of $\mathrm{P}_{\mathrm{i}}$ may have an important impact on photosynthetic activity, since $\mathrm{P}$ is a key component in energy transfer and signal transduction, as well as lipid biosynthesis for algae and cyanobacteria [22]. Once $\mathrm{P}_{\mathrm{i}}$-limitation sets in, it may cause severe change of photosynthesis in PCC6803, as has been noticed for other cyanobacteria [23]. Problems of $\mathrm{P}_{\mathrm{i}}$ depletion can be exacerbated when complexation of $\mathrm{HPO}_{4}{ }^{2-}$ and $\mathrm{PO}_{4}^{3-}$ with cations such as $\mathrm{Ca}^{2+}$ and $\mathrm{Mg}^{2+}$ reduces the availability of $\mathrm{P}_{\mathrm{i}}$ by forming octacalcium phosphate $\left(\mathrm{Ca}_{8}\left(\mathrm{HPO}_{4}\right)_{2}\left(\mathrm{PO}_{4}\right)_{4} \cdot 5 \mathrm{H}_{2} \mathrm{O}\right)$ and hydroxyapatite $\left(\mathrm{Ca}_{10}(\mathrm{OH})_{2}\left(\mathrm{PO}_{4}\right)_{6}\right)$, particularly as the $\mathrm{pH}$ increases [24].

In experiment 4 , we varied the $\mathrm{C}_{\mathrm{i}}$ concentration using $\mathrm{NaHCO}_{3}$ as the $\mathrm{C}_{\mathrm{i}}$ source, not by aeration. This ensured that our results were not confounded by mass transfer resistance from $\mathrm{CO}_{2(\mathrm{~g})}$ to $\mathrm{CO}_{2(\mathrm{aq})}$. The $\mathrm{pH}$ was maintained at 8 with a phosphate buffer; thus, the mass distribution between $\mathrm{CO}_{2(\text { aq })}$ and $\mathrm{HCO}_{3}^{-}$, the $\mathrm{C}_{\mathrm{i}}$ sources for PCC6803 [25], was fixed at a molar ratio of 1:49. The corresponding test ranges for $\mathrm{CO}_{2(\mathrm{aq})}$ and $\mathrm{HCO} 3-$ were 0-5.6 mgC/L and $0-279 \mathrm{mgC} / \mathrm{L}$, respectively.

Fig. 4 illustrates a clear Monod-like relationship between $\mu_{\text {syn }}$ and the $C_{i}$ concentration. The experimentally observed value peaked at around 1.5/d for $\mathrm{C}_{\mathrm{i}}$. Setting the maximum specific growth rate as $\mu_{\mathrm{syn}, \mathrm{LI}}=1.6 / \mathrm{d}$ (from $\mathrm{L}_{\mathrm{SA}}$ and experiment 1 ) gave an excellent match with the experimental results, and nonlinear regression estimated $\mathrm{K}_{\mathrm{S}}, \mathrm{C}_{\mathrm{i}}=0.6 \mathrm{mgC} / \mathrm{L}$ for total $\mathrm{C}_{\mathrm{i}}$. Thus, PCC6803 had a high affinity for $\mathrm{C}_{\mathrm{i}}$ when $\mathrm{HCO}_{3}{ }^{-}$was the dominant species at $\mathrm{pH}$ around 8. Due to its large dominance over $\mathrm{CO}_{2(\mathrm{aq})}$ in solution, $\mathrm{HCO}_{3}^{-}$probably was the species taken up by PCC6803 in these experiments [26], and $\mathrm{K}_{\mathrm{S}, \mathrm{Gi}},=0.6 \mathrm{mgC} / \mathrm{L}$ probably corresponds to the $\mathrm{K}_{\mathrm{S}}$ value for $\mathrm{HCO}_{3}^{-}$. The $\mathrm{C}_{\mathrm{i}}$ concentration needed to achieve $\mu_{\text {syn }}$ of $1 / \mathrm{d}$ is approximately $1.0 \mathrm{mgC} / \mathrm{L}$, which is intermediate between $0.1 \mathrm{mgP} / \mathrm{L}$ and $2.3 \mathrm{mgN} / \mathrm{L}$.

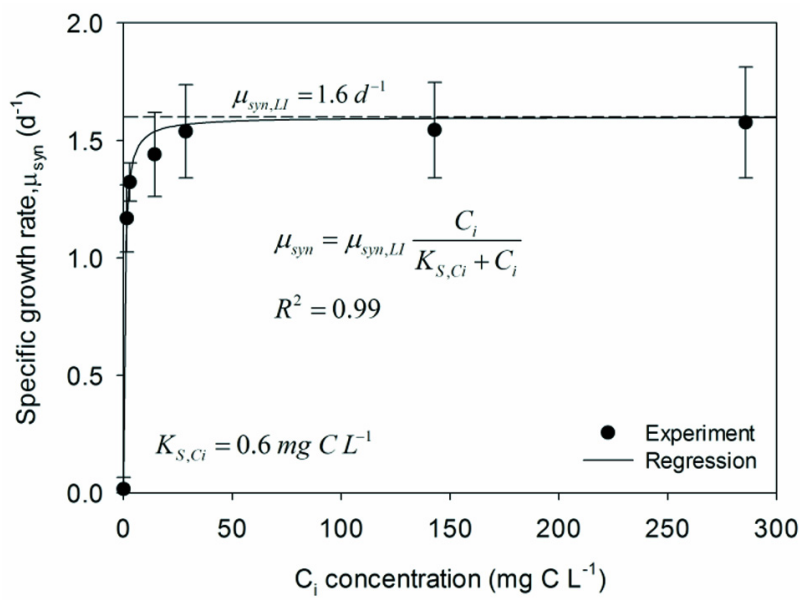

Fig. 4. Specific growth rates $\left(\mu_{\text {syn }}\right)$ for the range of $C_{i}$ concentrations for experiment 4 and the corresponding regression results using a Monod model (inset). At $\mathrm{pH} 8$, the molar ratio of $\mathrm{CO}_{2 \text { (aq) }}: \mathrm{HCO}_{3}{ }^{-}: \mathrm{CO}_{3}{ }^{2-}$ $=1.9: 97.6: 0.5$.

\subsection{Interpretation of Kinetic Parameters for the Nutrients}

Table 2 compares our LI parameters to literature values obtained for other cyanobacteria and algae. Our $\mathrm{K}_{\mathrm{L}}$ value was similar to other results $\left(6-18 \mathrm{~W} / \mathrm{m}^{2}\right)$, but $\mathrm{K}_{\mathrm{L}, \mathrm{I}}$ was considerably smaller than previously reported values. Most notably, Synechococcus sp. PCC7942 had a reported $\mathrm{K}_{\mathrm{L}, \mathrm{I}}$ of $97 \mathrm{~W} / \mathrm{m}^{2}$ [27], although light attenuation was not considered in the estimation. Using $\mathrm{LI}_{\mathrm{SA}}$ instead of LIO would make their $\mathrm{K}_{\mathrm{L}, \mathrm{I}}$ smaller: $\sim 77 \mathrm{~W} / \mathrm{m}^{2}$ based on the analysis presented in Supporting Information (Table S3 and Fig. S5). Thus, the comparison of $\mathrm{K}_{\mathrm{L}, \mathrm{I}}$ values suggests that PCC6803 is relatively more sensitive to photo-inhibition than are other phototrophs that have been evaluated. However, significant negative impacts of LI self-inhibition require a substantially greater $\mathrm{LI}_{\mathrm{SA}}$ value than $\sim 62 \mathrm{~W} / \mathrm{m}^{2}$ (Fig. 1).

Table 3 also shows all of our $\mathrm{K}_{\mathrm{S}}$ and $\mu_{\max }$ values together with literature values obtained with other algae or cyanobacteria. Compared to ranges for algal species with reported $\mu_{\max }$ values $(0.7-1.7 / \mathrm{d})$, PCC6803 had by far the highest $\mu_{\max }(2.8 / \mathrm{d})$, although the highest observed $\mu_{\text {syn,LI }}$ was $1.6 / \mathrm{d}$ due to photo-inhibition. The relatively high $\mu_{\max }$ values suggests that PCC6803 behaves as an r-strategist, or a copiotroph that employs a rapid-growth strategy

Table 2. Comparisons of Kinetic Parameters using the Self-inhibition Model for Light Irradiance for Cyanobacteria and Algae

\begin{tabular}{|c|c|c|c|c|}
\hline Photosynthetic Microorganisms & Dependent Parameter & $K_{L}\left(W / m^{2}\right)$ & $K_{L, I}\left(W / m^{2}\right)$ & Reference \\
\hline Synechococcus sp. PCC7942 & Photosynthetic production of Ethylene & $5.8 \mathrm{~b}$ & $97 \mathrm{~b}$ & [27] \\
\hline Spirulina platensis & Specific growth rate & 10 & 180 & {$[32]$} \\
\hline Anabaena flos-aquae & Specific growth rate & 14 & 61 & {$[33]$} \\
\hline Synechocystis sp. PCC6803 & Specific growth rate & 11 & 39 & This study \\
\hline Chlamydomonas reinhardtii ${ }^{\mathrm{a}}$ & Specific growth rate ${ }^{\mathrm{c}}$ & 18 & 540 & [34] \\
\hline Chlorella vulgaris ${ }^{\mathrm{a}}$ & Photosynthetic activity & $11 \mathrm{~d}$ & - & {$[35]$} \\
\hline
\end{tabular}

a Algae

b The unit of lumen $\mathrm{m}^{-2}$ (lx) was converted to $\mathrm{W} / \mathrm{m}^{2}$ by assuming the luminous efficacy of radiation as natural sunlight (93 lumen/W). Supporting Information shows the result of LI-adjustment to LISA as PAR

${ }^{c}$ Estimated by using a continuous reactor

${ }^{d}$ The unit of $\mathrm{mE} / \mathrm{m}^{2} / \mathrm{s}$ was converted to $\mathrm{W} / \mathrm{m}^{2}$ by assuming $1 \mathrm{~W} / \mathrm{m}^{2}$ as $4.6 \mathrm{mE}$ photon $/ \mathrm{m}^{2} / \mathrm{s}$ 
Table 3. Comparisons of $\mu_{\max }$ and $\mathrm{K}_{\mathrm{s}}$ Values for $\mathrm{C}_{\mathrm{i}}, \mathrm{N}_{\mathrm{i}}$, and $\mathrm{P}_{\mathrm{i}}$ using Monod Kinetics with a Range of Phototrophic Microorganisms

\begin{tabular}{|c|c|c|c|c|}
\hline Photosynthetic organisms & Target nutrient & $\mu_{\max }\left(d^{-1}\right)$ & $\mathrm{K}_{\mathrm{s}}(\mathrm{mg} / \mathrm{L})$ & Reference \\
\hline Chlorella $^{\mathrm{a}}$ & \multirow{4}{*}{$\mathrm{C}_{\mathrm{i}}$} & 1.7 & 0.003 & \multirow{3}{*}[36]{} \\
\hline Anabaena flos aquae ${ }^{\mathrm{b}}$ & & 1.3 & 0.002 & \\
\hline Oscillitoria $^{\mathrm{b}}$ & & 0.7 & 0.005 & \\
\hline Synechocystis sp. PCC6803 ${ }^{\mathrm{b}}$ & & 2.8 & 0.5 & This study \\
\hline Chlorella vulgaris ${ }^{\mathrm{a}}$ & \multirow{7}{*}{$\mathrm{N}_{\mathrm{i}}$} & 0.2 & 32 & {$[31] \mathrm{c}$} \\
\hline Spirulina platensis $8005^{\mathrm{b}}$ & & - & 5.3 & [9] \\
\hline Ankistrodesmus falcatus ${ }^{\mathrm{a}}$ & & 1.2 & 0.13 & \multirow{4}{*}[37]{} \\
\hline Asterionella Formosa ${ }^{\mathrm{a}}$ & & 1.0 & 0.02 & \\
\hline Fragilaria crotonensis $^{\mathrm{a}}$ & & 0.9 & 0.11 & \\
\hline Scenedesmus sp. ${ }^{\mathrm{a}}$ & & 1.4 & 0.16 & \\
\hline Synechocystis sp. PCC6803 ${ }^{\mathrm{b}}$ & & 2.8 & 1.4 & This study \\
\hline Chlorella vulgaris ${ }^{\mathrm{a}}$ & \multirow{10}{*}{$\mathrm{P}_{\mathrm{i}}$} & 0.1 & 10.5 & [31] c \\
\hline Anabaena flos-aquae ${ }^{\mathrm{b}}$ & & 0.9 & 0.04 & \multirow{6}{*}{ [38] } \\
\hline Ankistrodesmus falcatus ${ }^{\mathrm{a}}$ & & 1.1 & 0.12 & \\
\hline Asterionella Formosa ${ }^{\mathrm{a}}$ & & 1.0 & 0.02 & \\
\hline Fragilaria crotonensis $^{\mathrm{a}}$ & & 0.9 & 0.03 & \\
\hline Microcystis sp. ${ }^{\mathrm{b}}$ & & 1.2 & 0.05 & \\
\hline Scenedesmus sp. ${ }^{\mathrm{a}}$ & & 1.4 & 0.02 & \\
\hline Synechococcus PCC7942 ${ }^{\mathrm{b}}$ & & - & 0.07 & {$[30]$} \\
\hline Cylindrospermopsis raciborskii ${ }^{\mathrm{b}}$ & & 1.0 & 0.002 & [39] \\
\hline Synechocystis sp. PCC6803 ${ }^{\mathrm{b}}$ & & 2.8 & 0.06 & This study \\
\hline
\end{tabular}

${ }^{\text {a }}$ algae; ${ }^{\mathrm{b}}$ cyanobacteria; ${ }^{\mathrm{c}} \mathrm{NH}_{4}{ }^{+}$was used as a nitrogen source to test wastewater treatment.

[28] that gives it a competitive advantage when conditions allow it to avoid significant limitation by LI or any of the inorganic nutrients.

The values of $\mathrm{K}_{\mathrm{S}, \mathrm{Gi}}$, reported for algae (0.002-0.005 mgC/L) are significantly lower than for PCC6803. This means that the growth rate of PCC6803 can be more easily limited by $\mathrm{C}_{\mathrm{i}}$, compared to algae, when an imbalance between supply and utilization of $\mathrm{CO}_{2}$ occurs. Thus, PCC6803 needs to have a sufficient $\mathrm{C}_{\mathrm{i}}$ supply rate to avoid $\mathrm{HCO}_{3}{ }^{-}$limitation, which would counteract it growth-rate advantage over algae.

Due to PCC6803's relative sensitivity to the $C_{i}$ concentration, it would be possible that high $\mathrm{pH}$ may slow the $\mathrm{C}_{\mathrm{i}}$-uptake kinetics by changing the dominant $\mathrm{C}$ form to $\mathrm{CO}_{3}^{2-}$, with $\mathrm{CO}_{2}(\mathrm{aq})$ becoming negligible because the concentrations of available $\mathrm{C}_{\mathrm{i}}$ species $-\mathrm{CO}_{2(\mathrm{aq})}$ and $\mathrm{HCO}_{3}{ }^{-}$- are determined by the $\mathrm{pH}$ [25]. The $\mathrm{pH}$ also affects the complexation equilibria of cationic and anionic species that can precipitate with $\mathrm{C}_{\mathrm{i}}$. High $\mathrm{pH}$ by active photosynthesis can lower the available $\mathrm{C}_{\mathrm{i}}$ by precipitating it as part of $\mathrm{CaCO}_{3}$.

Similar to $\mathrm{C}_{\mathrm{i}}$, PCC6803 is more easily limited by low $\mathrm{N}_{\mathrm{i}}$, compared to other phototrophs for which we have reports [16, 29]. Although our estimated $\mathrm{K}_{\mathrm{S}, \mathrm{Ni}}(1.4 \mathrm{mgN} / \mathrm{d})$ is not far from a literature value (5.3 $\mathrm{mgN} / \mathrm{L}$ ) obtained for Spirulina platensis [9], which, like Synechocystis, is a non-diazotrophic cyanobacterium [20], several algae show $\mathrm{K}_{\mathrm{S}, \mathrm{Ni}}$ values about one order of magnitude lower (0.02 0.16 mgN/L).

Unlike for $\mathrm{C}_{\mathrm{i}}$ and $\mathrm{N}_{\mathrm{i}}$, PCC6803 is not more severely limited by $\mathrm{P}_{\mathrm{i}}$ than are other phototrophs. A study using the cyanobacterium Synechococcus sp. PCC7942 reported $\mathrm{K}_{\mathrm{S}, \mathrm{Pi}}=0.07 \mathrm{mgP} / \mathrm{L}$ [30], almost identical with our result $(0.06 \mathrm{mgP} / \mathrm{L})$. In addition, the $\mathrm{K}_{\mathrm{S}, \mathrm{Pi}}$ values of several algae were in a similar range, 0.02 to $0.12 \mathrm{mgP} / \mathrm{L}$, although one report was much higher [31]. Such similarity may indicate that utilization mechanisms of $\mathrm{P}_{\mathrm{i}}$ are invariant.

\section{Conclusions}

We use a series of special batch experiments to estimate parameter values for a multi-component kinetic model of photoautotrophic growth. Results for the cyanobacterium Synechocystis PCC6803 quantify its growth-rate limitation by $\mathrm{LI}_{\mathrm{SA}}$ or the concentration of $\mathrm{C}_{\mathrm{i}}, \mathrm{N}_{\mathrm{i}}$, or $\mathrm{P}_{\mathrm{i}}$. With $\mu_{\max }=2.8 / \mathrm{d}$, PCC6803 is an r-strategist (or copiotroph) that can grow fast when light and nutrients do not limit. This is ideal when the goal is to maximize the biomass production rate, such as for biomass production as a renewable source of biofuels and biomaterials. To gain the advantages of its high maximum specific growth rate, PCC6803 needs to have moderate light illumination $\left(7-62 \mathrm{~W} / \mathrm{m}^{2}\right.$ for $\left.\mu_{\text {syn }} \geq 1 / \mathrm{d}\right)$ and relatively high nutrient concentrations: $\mathrm{N}_{\mathrm{i}} \geq 2.3 \mathrm{mgN} / \mathrm{L}, \mathrm{P}_{\mathrm{i}} \geq 0.1 \mathrm{mgP} / \mathrm{L}$, and $\mathrm{C}_{\mathrm{i}} \geq 1.0 \mathrm{mgC} / \mathrm{L}$.

\section{Acknowledgements}

We are grateful to the Advanced Research Projects Agency-Energy (ARPA-E) of the United States Department of Energy for their generous financial support. We thank Drs. Willem Vermass, Roy 
Curtiss, Rosa Krajmalnik-Brown, and David Nielsen and their laboratories in, respectively, the School of Life Sciences, School of Sustainable Engineering and the Built Environment, and the School for Engineering of Matter, Transport and Energy at Arizona State University for assistance and advice on PCC6803, experimental designs, and data analysis. In addition, This work was financially supported by the Research Program for Agriculture Science \& Technology Development (Project No. PJ01082403 2015), Rural Development Administration, Korea.

\section{Supplementary Information}

Supplementary data to this article can be found online at http://eeer.org.

\section{References}

1. Wahlen BD, Morgan MR, McCurdy AT, et al. Biodiesel from Microalgae, Yeast, and Bacteria: Engine Performance and Exhaust Emissions. Energy \& Fuels. 2012;27:220-228.

2. Campbell JE, Lobell DB, Field CB. Greater Transportation Energy and GHG Offsets from Bioelectricity Than Ethanol. Science 2009;324:1055-1057.

3. Rittmann BE. Opportunities for renewable bioenergy using microorganisms. Biotechnol. Bioeng. 2008;100:203-212.

4. Berg JM, Tymoczko JL, Stryer L. Biochemistry. 6 ed: W.H. Freeman; 2006.

5. Fernandez FGA, Camacho FG, Perez JAS, Sevilla JMF, Grima EM. A model for light distribution and average solar irradiance inside outdoor tubular photobioreactors for the microalgal mass culture. Biotechnol. Bioeng. 1997;55:701-714.

6. Wolf G, Picioreanu C, van Loosdrecht MCM. Kinetic modeling of phototrophic biofilms: The PHOBIA model. Biotechnol. Bioeng. 2007;97:1064-1079.

7. Ogbonna JC, Tanaka H. Light requirement and photosynthetic cell cultivation - Development of processes for efficient light utilization in photobioreactors. J. Appl. Phycol. 2000;12:207-218.

8. Andrews JF. A mathematical model for continuous culture of microorganisms utilizing inhibitory substrates. Biotechnol. Bioeng. 1968;10:707-723.

9. Cornet JF, Dussap CG, Cluzel P, Dubertret G. A structured model for simulation of cultures of the cyanobacterium Spirulina-Platensis in photobioreactors: II. Identification of kinetic-parameters under light and mineral limitations. Biotechnol. Bioeng. 1992;40:826-834.

10. Bae W, Rittmann BE. Responses of intracellular cofactors to single and dual substrate limitations. Biotechnol. Bioeng. 1996;49:690-699.

11. Suh IS, Lee SB. A light distribution model for an internally radiating photobioreactor. Biotechnol. Bioeng. 2003;82:180-189.

12. Evers EG. A model for light-limited continuous culturesGrowth, shading, and maintenance. Biotechnol. Bioeng. 1991; 38:254-259.

13. Mikami K, Kanesaki Y, Suzuki I, Murata N. The histidine kinase Hik33 perceives osmotic stress and cold stress in Synechocystis sp PCC 6803. Mol. Microbiol. 2002;46:905-915.

14. Angermayr SA, Hellingwerf KJ, Lindblad P, de Mattos MJT. Energy biotechnology with cyanobacteria. Curr. Opin. Biotechnol. 2009;20:257-263.

15. McCree KJ. Test of current difinitions of photosynthetically active radiation against leaf photosynthesis data. Agric. Meteorol. 1972;10:443-453.

16. Kim HW, Vannela R, Zhou C, Harto C, Rittmann BE. Photoautotrophic Nutrient Utilization and Limitation During Semi-Continuous Growth of Synechocystis sp PCC6803. Biotechnol. Bioeng. 2010;106:553-563.

17. Rippka R, Deruelles J, Waterbury JB, Herdman M, Stanier RY. Generic assignments, strain histories and properties of pure cultures of cyanobacteria. J. Gen. Microbiol. 1979;111:1-61.

18. Snoeyink VL, Jenkins D. Water Chemistry. New York: John Wiley \& Sons; 1980.

19. Eaton AD, Clesceri LS, Rice EW, Greenberg AE, Franson MAH. Standard Methods for the Examination of Water and Wastewater. 21 ed. Washington, D.C.: American Public Health Association; 2005.

20. Allen MM, Smith AJ. Nitrogen chlorosis in blue-green algae. Arch. Mikrobiol. 1969;69:114-120.

21. Stevens SE, Balkwill DL, Paone DAM. The effects of nitrogen limitation on the ultrastructure of the cyanobacterium Agmenellum-Quadruplicatum. Arch. Microbiol. 1981;130:204-212.

22. Guschina IA, Dobson G, Harwood JL. Lipid metabolism in cultured lichen photobionts with different phosphorus status. Phytochemistry 2003;64:209-217.

23. Stevens SE, Paone DAM, Balkwill DL. Accumulations of cyanophycin granues as a result of phosphate limitation in Agmenellum-Quadruplicatum. Plant Physiol. 1981;67:716-719.

24. Lu X, Leng Y. Theoretical analysis of calcium phosphate precipitation in simulated body fluid. Biomaterials 2005;26:1097-1108.

25. Ogawa T, Kaplan A. Inorganic carbon acquisition systems in cyanobacteria. Photosyn. Res. 2003;77:105-115.

26. Shibata M, Ohkawa H, Katoh H, Shimoyama M, Ogawa T. Two $\mathrm{CO}_{2}$ uptake systems in cyanobacteria: four systems for inorganic carbon acquisition in Synechocystis sp strain PCC6803. Funct. Plant Biol. 2002;29:123-129.

27. Wang JS, Araki T, Ogawa T, Matsuoka M, Fukuda H. A method of graphically analyzing substrate-inhibition kinetics. Biotechnol. Bioeng. 1999;62:402-411.

28. Rittmann BE, McCarty PL. Environmental Biotechnology: Principles and Applications: McGraw-Hill Publishing Co.; 2001.

29. Kim HW, Vannela R, Zhou C, Rittmann BE. Nutrient Acquisition and Limitation for the Photoautotrophic Growth of Synechocystis sp PCC6803 as a Renewable Biomass Source. Biotechnol. Bioeng. 2011;108:277-285.

30. Ritchie RJ, Trautman DA, Larkum AWD. Phosphate uptake in the cyanobacterium Synechococcus R-2 PCC 7942. Plant Cell Physiol. 1997;38:1232-1241.

31. Aslan S, Kapdan IK. Batch kinetics of nitrogen and phosphorus removal from synthetic wastewater by algae. Ecol. Eng. 2006;28:64-70. 
32. Lee HY, Erickson LE, Yang SS. Kinetics and bioenergetics of ligh-limited photoautotrophic growth of Spirulina-Platensis. Biotechnol. Bioeng. 1987;29:832-843.

33. Lee DY, Rhee GY. Kinetics of growth and death in Anabaena flos-aquae (cyanobacteria) under light limitation and supersaturation. J. Phycol. 1999;35:700-709.

34. Fouchard S, Pruvost J, Degrenne B, Titica M, Legrand J. Kinetic Modeling of Light Limitation and Sulfur Deprivation Effects in the Induction of Hydrogen Production With Chlamydomonas reinhardtii: Part I. Model Development and Parameter Identification. Biotechnol. Bioeng. 2009;102:232-245.

35. Yun YS, Park JM. Kinetic modeling of the light-dependent photosynthetic activity of the green microalga Chlorella vulgaris. Biotechnol. Bioeng. 2003;83:303-311.

36. Novak JT, Brune DE. Inorganic carbon limited growth-kinetics of some fresh-water algae. Water Res. 1985;19:215-225.

37. Gotham IJ, Rhee GY. Comparative kinetic-studies of nitrate-limited growth and nitrate uptake in photoplankton in continuous culture. J. Phycol. 1981;17:309-314.

38. Gotham IJ, Rhee GY. Comparative kinetic-studies of phosphate-limited growth and phosphate uptake in photoplankton in continuous culture. J. Phycol. 1981;17:257-265.

39. Isvánovics V, Shafik HM, Présing M, Juhos S. Growth and phosphate uptake kinetics of the cyanobacterium, Cylindrospermopsis raciborskii (Cyanophyceae) in throughflow cultures. Freshw. Biol. 2000;43:257-275. 